\title{
Peran Geografi Dalam Pembentukan Karakter dan Keterampilan Manusia Indonesia Pada Era Masyarakat Ekonomi ASEAN
}

\author{
Saiful Khafid ${ }^{*}$ \\ ${ }^{1}$ Dinas Pendidikan, Jawa Timur, Indonesia \\ *e-mail: syaiful.khafid@yahoo.co.id
}

Article history: Received 05 February 2020; Accepted 17 April 2020; Available online 30 April 2020

\begin{abstract}
Abstrak
Tujuan kajian ini adalah untuk mendeskripsikan Indonesia dalam fenomena paradoksial, karakter manusia Indonesia yang diharapkan dalam MEA, keterampilan manusia Indonesia yang dibutuhkan dalam MEA, dan peran geografi sebagai pendidikan global untuk meningkatkan kualitas SDM Indonesia. Penelitian ini adalah kajian literer. Data diperoleh melalui instrumen rekam dan kartu data dengan analisis konten dan hermeneutik.

Kata Kunci:

Geografi;

Pembentukan

Karakter;

Keterampilan;

Manusia Indonesia;

$M E A$

Hasil kajian menunjukkan Indonesia masih berparadoksial disebabkan virus orientasi sebagai penghambat pembangunan. Karakter manusia Indonesia diharapkan dalam MEA di abad pengetahuan adalah cerdas dan waras sesuai nilai-nilai dasar Pancasila dan gaya liberal ala Puntsch. Keterampilan dasar manusia Indonesia yang dibutuhkan adalah berpikir dan berbuat secara kritis, kreativitas, kolaborasi, saling pengertian lintas budaya, komunikasi, menggunakan komputer dan internet, dan karier dan belajar mempercayai diri sendiri. Peran pendidikan global dapat membantu manu-sia memahami dan merefleksikan keadaan masyarakat global. Geografi sebagai pendidikan global dalam memahami dunia dan merefleksikan kondisi atau situasi masyarakat global dalam MEA sebagai tuntutan dan tantangan abad pengetahuan.
\end{abstract}

\begin{abstract}
This study aims to describe Indonesia in a paradoxical phenomenon, the expected Indonesian human character in the AEC, the Indonesian human skills needed in the AEC, and the role of geography as global education to improve the quality of human resources Indonesia. This research is a literary study.

Keywords: Geography; Character Building; Skills; Indonesian People; $A E C$ Data was obtained through the recording instruments and data cards with content analysis and hermeneutics. The results of the study show that Indonesia is still paradoxical through orientation viruses as a barrier to development. The Indonesian human character expected in the MEA in the knowledge age is intelligent and sane according to the fundamental values of Pancasila and the liberal style of the Puntsch style. The necessary skills of Indonesian people needed are critical thinking and acting, creativity, collaboration, cross-cultural understanding, communication, using computers and the internet, and career and learning to trust ourselves. The role of global education can help people understand and reflect the state of a global society. Geography as a global education in understanding the world and reflecting the conditions or situation of the global community in the AEC as the demands and challenges of the knowledge age.
\end{abstract}

Copyright (C) Universitas Pendidikan Ganesha. All rights reserved

\section{Pendahuluan}

Kesejahteraan bangsa Indonesia bukan lagi bersumber pada kekayaan alam dan modal yang bersifat fisik, melainkan bersumber pada sumber daya manusia berupa modal intelektual, modal sosial, dan kredibilitas sehingga tuntutan untuk terus menerus memutakhirkan pengetahuan menjadi suatu keharusan. Mutu lulusan tidak cukup jika diukur dengan standar nasional saja, sebab perubahan global pada abad pengetahuan mempengaruhi ekonomi suatu bangsa (Muzakki, 2015). Terlebih lagi, industri baru dikembangkan berdasarkan pengetahuan 
kompetensi tingkat tinggi maka bangsa yang berhasil adalah bangsa yang berpendidikan dengan standar kualitas tinggi.

Persoalan sumber daya munusia sebagai akibat praksis pendidikan yang kita hadapi sekarang ini sebenarnya terjadi karena krisis paradigma, yaitu kesenjangan atau ketidaksesuaian antara tujuan yang ingin dicapai dengan paradigma yang digunakan untuk mencapai tujuan tersebut (Ardhana, 2001). Paradigma diartikan sebagai pola pikir (cara kerja) Sebagai contoh, kalau kehidupan masa depan menuntut kemampuan memecahkan masalah baru secara inovatif, apa yang diajarkan kepada siswa di sekolah adalah menghafal atau memecahkan masalah lama secara lebih baik. Kalau masa depan menuntut pola perilaku unik dan divergen, apa yang ditanamkan kepada siswa kita sekarang adalah pola perilaku konformistis dan seragam. Begitu juga, kalau masa depan menuntut kemampuan kerja sama dengan sesama teman, apa yang kita belajarkan kepada siswa sekarang adalah kompetisi. Hal ini tidak relevan dengan tuntutan abad pengetahuan lebih-lebih kalau dikaitkan dengan perkembangan ipteks (Utami, Sakitri, \& Sebayang, 2016).

Perkembangan ipteks yang terjadi sangat cepat sekarang ini menimbulkan perubahan yang cepat pula dalam berbagai aspek kehidupan masyarakat. Oleh karena itu, abad XXI digambarkan oleh futurists sebagai abad pengetahuan (the knowledge age), sebab pengetahuan akan menjadi landasan utama semua aspek kehidupan. Pekerjaan masa depan, begitu juga perekonomian masa depan akan sarat dengan landasan pengetahuan untuk persaingan ekonomi masyarakat ASEAN (MEA). Oleh karena itu, ekonomi masa depan sering juga disebut ekonomi berbasis pengetahuan (the knowledge economy).

Indonesia masih menghadapi beberapa tantangan baik eksternal maupun internal dalam penyelenggaraan MEA. Tantangan eksternal berupa tingkat persa-ingan perdagangan yang semakin ketat, semakin besarnya defisit neraca perda-gangan Indonesia dengan negara ASEAN lainnya, dan bagaimanakah Indonesia meningkatkan daya tarik investasi. Sementara itu, tantangan internal di antaranya: rendahnya pemahaman masyarakat terhadap MEA, ketidaksiapan daerah meng-hadapi MEA, tingkat pembangunan daerah masih bervariasi, dan kondisi sumber daya manusia masih bermasalah berkaitan dengan kompetensi dan mentalitas. Salah satu penyebab utama adalah penyelenggaraan pendidikan yang kurang sesuai dengan falsafah pendidikan keindonesiaan berbasis global dan marginali-sasi geografi sebagai pendidikan global.

Indonesia merasa kurang siap menghadapi MEA 2015 yang diberlakukan mulai awal 2016. Hasil penelitian yang dilakukan Triyonggo (2015) dengan responden valid 177 orang, "lebih dari setengah responden menyatakan kurang siap menghadapi sehingga proses percepatan pengembangan kompetensi dan karakter manusia Indonesia perlu ditingkatkan daya kompetisi regional dan global." Kompetensi penting yang dibutuhkan manusia Indonesia dalam konteks MEA adalah berpikir komputasional dan kompasi (compassion) melalui sekolah (Dahliyana, 2017).

Sekolah dalam bentuknya yang sekarang masih belum bisa digantikan meski masih banyak kesalahan mendasar, baik kesalahan konseptual maupun praktikal Bagir (2019), atau kesalahan akademik dan manajerial. Mulai dari kerancuan tentang tujuan pendidikan, kesalahpahaman terhadap hakikat kemanu-siaan sebagai subjek pendidikan, kekaburan tentang hakikat proses belajar, dan sedikit model pembelajaran yang diterapkan dalam pembelajaran. Karena itu, seharusnya pendidikan ialah suatu kegiatan untuk mengaktualkan potensi manusia sehingga benar-benar menjadi manusia sejati melalui penerapan prinsip merdeka belajar sebagai kebutuhan hidupnya di abad pengetahuan yang sarat tantangan dan gejolak ketidakpastian. Shihab \& Komunitas Guru Belajar (2017) menggagas merdeka belajar sebagai solusi permasalahan pendidikan tingkat persekolahan. Guru dan siswa harus komitmen pada tujuan instruksional. Belajar sebagai kebutuhan utama untuk bisa hidup di abad pengetahuan (Ismuha \& Dkk, 2016).

Berdasarkan pemaparan latar belakang tersebut, adapun permasalahan yang akan dikaji dalam penelitian ini sebagai berikut. Mengapa Indonesia terjebak dalam fenomena paradoksial 
dalam merespons MEA? Bagaimana karakter manusia Indonesia yang diharapkan dalam MEA? Apa saja keterampilan manusia Indonesia yang dibutuhkan dalam MEA? Bagaimana peran geografi dunia sebagai pendidikan global untuk meningkatkan kualitas SDM Indonesia dalam menyikapi perdagangan bebas di lingkungan MEA?

\section{Metode}

Penelitian ini adalah kajian literer (studi pustaka) yang aeluruh materinya memerlukan olahan filosofis dan teoretis yang terkait dengan karakter dan kete-rampilan manusia Indonesia dalam MEA tuntutan abad pengetahuan melalui peran geografi sebagai pendidikan global. Karena sifatnya yang filosofis, kajian ini menggunakan filosofis kualitatif dalam bentuk analisis sistematis pola pikir induksi, fenomenologis, dan reflektif.

Penelitian ini bersifat literer, karena itu data yang dikumpulkan adalah berasal dari buku, web, dan jurnal yang relevan (Hamzah, 2019). Data tersebut dikumpulkan dengan teknik dokumentasi, yakni dengan cara membaca, mengkaji, mempelajari, dan mencatat esensi isi literatur tersebut. Data diperoleh melalui instrumen rekam atau fotokopi dan kartu data.

Teknik analisis data dalam kajian ini adalah analisis konten. Dalam proses ini data-data itu diklasifikasi menurut signifikansinya, kemudian direfleksikan dan diberi pemaknaan. Dalam hal ini, data-data tersebut dideskripsikan, diinterpretasi, dinilai, dipahami, dan dianalisis yang sangat bergantung pada penggunaannya dalam kalimat. Untuk membantu dinamika pemahaman data-data dari teks itu, Sumaryono (1999) memakai "analisis hermeneutik." Artinya, sebuah teks bukan diperlakukan sebagai benda mati melainkan dihidupkan rohnya. Karena itu dalam analisis ini, tidak dikenal penafsiran final dan selalu terbuka penafsiran lain sehingga terjadi saling penafsiran antarteks.

\section{Hasil dan Pembahasan}

\section{Indonesia dalam Fenomena Paradoksial di Segala Bidang Kehidupan}

Ekonomi pengetahuan berkembang dari dua tahap perkembangan, yaitu ekonomi industri (manufaktur) dan ekonomi pertanian (agraris) yang dalam sejarah perkembangannya telah banyak mengubah kehidupan umat manusia dari kehidupan sederhana (primitif) menuju masyarakat modern. Ciri-ciri setiap tahap perkembangan ekonomi dapat dilihat pada Gambar dan Tabel berikut.

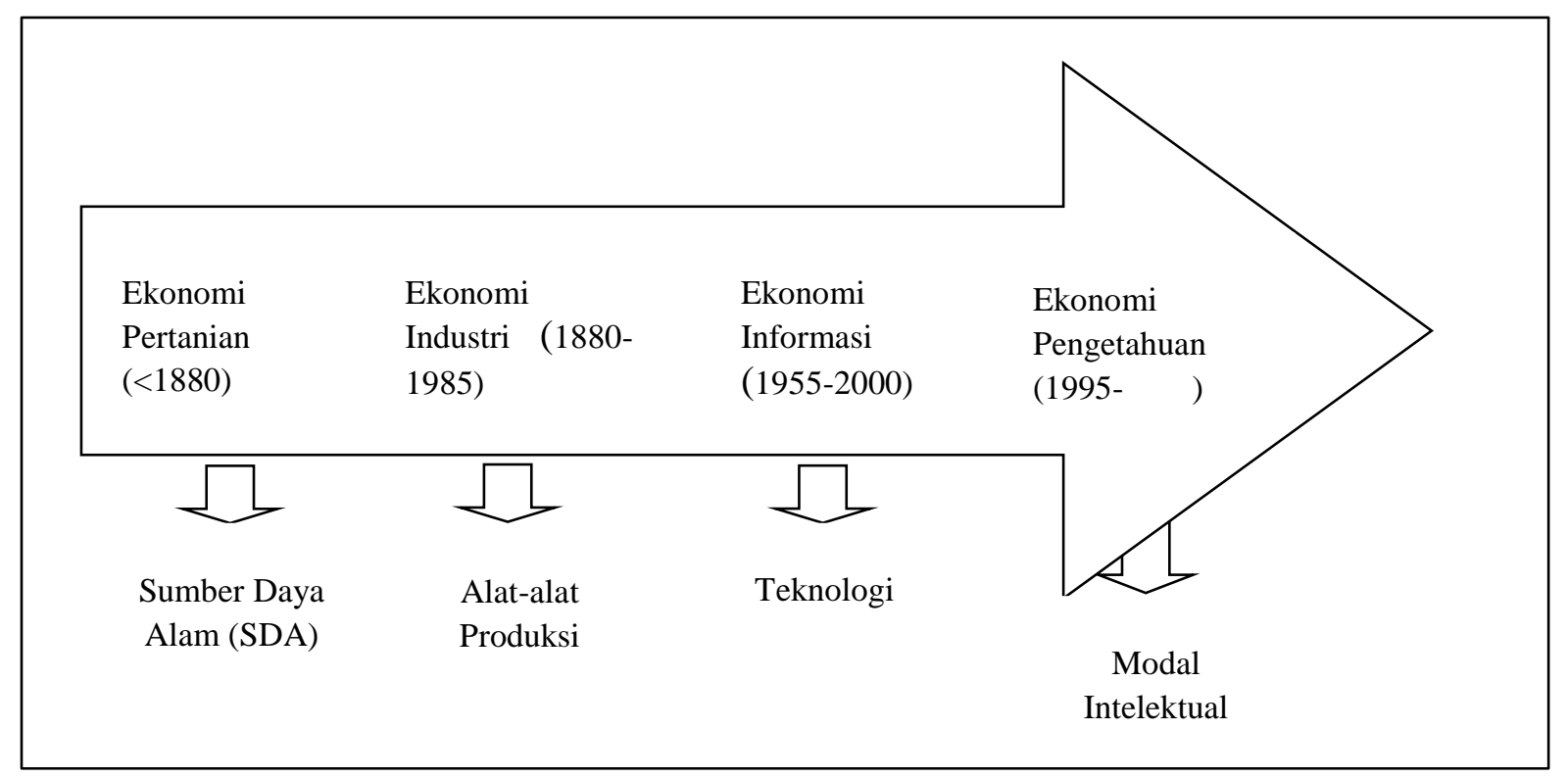

Gambar 1. Perkembangan menuju Ekonomi Pengetahuan dan Sumberdaya Pendukungnya

(Sumber: Galbreath, 1999) 
Tabel 1. Tingkat Perkembangan Ekonomi

\begin{tabular}{llll}
\hline Aspek & Pertanian & Industri & Pengetahuan \\
\hline Teknologi dominan & Bajak & Mesin & Komputer \\
Ilmu yang melandasi & Rekayasa sipil & Rekayasa mekanik & Rekayasa biologi \\
Tujuan & Bertahan hidup & Kekayaan materi & Pertumbuhan pribadi \\
Keluaran & Makanan & Barang & Informasi \\
Sumberdaya strategis & Tanah & Modal & Pengetahuan \\
Bentuk organisasi & Keluarga & Korporasi & Jaringan \\
Sumber energi & Binatang & Minyak bumi & Pikiran \\
Pekerjaan utama & Petani & Buruh & Enteprenur \\
Sifat produksi & Sendiri & Massal & Individu \\
\hline Sumber: Ardhana & &
\end{tabular}

Sumber: Ardhana (2001)

Berdasarkan gambar dan tabel di atas, dalam menjalani hidup dengan masyarakat ekonomi ASEAN dan tuntutan abad pengetahuan seharusnya tingkat perekonomian Indonesia adalah ekonomi pengetahuan dengan mengandalkan modal intelektual dan informasi pengetahuan dengan indikasi teknologi yang dominan berupa komputer, ilmu pengetahuan yang melandasi yaitu rekayasa biologi, tujuan ialah pertumbuhan pribadi, sumberdaya strategi berupa penge-tahuan, bentuk organisasi berupa jaringan, sumber energi berwujud pikiran, pekerjaan utama ialah enteprenur, dan sifat produksi ialah individu. Akan tetapi apa kenyataannya Indonesia masih terjebak dalam fenomena paradoksial.

Permasalahan yang merupakan fenomena paradoksial tentang Indonesia pada era perdagangan bebas di lingkungan Masyarakat Ekonomi ASEAN (MEA) 2015 dan harapan terhadap generasi emas 2045. Fenomena ini dikemukakan oleh BJ Habibie pada Silaknas di Kendari 2011 sebagai berikut. Pertama, kita kaya tetapi miskin (kekayaan SDA melimpah, tetapi miskin pendapatan, penghasilan untuk hidup tidak layak). Kedua, kita besar tetapi kerdil (amat besar wilayah dan penduduknya, tetapi kerdil dalam produktivitas dan daya saing). Ketiga, kita kuat tetapi lemah (kuat dalam anarkisme, tetapi lemah dalam tan-tangan global). Keempat, kita indah tetapi buruk (indah dalam potensi dan prospeknya, tetapi buruk dalam pengelolaannya) (Sugiharto, 2012).

Mengapa terjadi paradoksial (pernyataan yang seolah-olah bertentangan/ perlawanan dengan pendapat umum/publik atau kebenaran, tetapi kenyataannya mengandung kebenaran)? Hal ini disebabkan kita terkena virus atau penyakit orientasi, kurang lebih sebagai berikut. Kita lebih mengandalkan SDA daripada $\boldsymbol{S D M}$ Kita lebih berorientasi jangka pendek daripada jangka panjang. Kita lebih mengutamakan citra daripada karya nyata. Kita lebih melirik makro daripada mikro. Kita lebih mengandalkan cost added daripada value added. Kita lebih berorientasi pada neraca pembayaran dan perdagangan daripada neraca jam kerja. Kita lebih menyukai jalan pintas (korupsi, kolusi, nepotis, dan menghalal-kan segala cara) daripada kejujuran dan kebajikan. Kita lebih menganggap jabatan (power) sebagai tujuan memperkaya diri daripada sebagai sarana untuk melaksanakan amanah.

\section{Karakter Manusia Indonesia yang Diharapkan dalam MEA pada Abad Pengetahuan}

Berbicara tentang masalah kualitas manusia dalam pembangunan, kita perlu mengkaji beberapa aspek diri manusia (Thobroni \& Mustofa, 2011). Pertama, aspek fisik berupa tingkat kesehatan tubuh dan kelengkapan anggota tubuh. Kedua, aspek kognitif, dalam hal ini tingkat kecerdasan dan pendidikan. Ketiga, aspek nonkognitif, yaitu kualitas kepribadian dan kualitas moral yang ada pada diri seseorang. Seseorang tidak dapat menjadi pekerja produktif kalau kesehatannya kurang baik, kemampuan kognitifnya tidak sesuai dengan tuntutan pekerjaan, dan moralnya tidak sejalan dengan kehendak pembangunan. Kemam-puan kognitif, dan nonkognitif yang baik, berindikasi bahwa manusia itu cerdas dan waras. 
Ciri nonkognitif manusia Indonesia yang diperlukan oleh pembangunan pada abad pengetahuan bukanlah masalah mudah untuk dilakukan (Thobroni dan Mustofa, 2011). Kesulitan utama yang dihadapi di dalam membicarakan masalah ini ialah sedikitnya hasil-hasil penelitian ilmiah yang membahas kualitas manusia dalam kaitannya dengan kemajuan pembangunan di suatu negara. Kesulitan yang lain ialah manusia terpaksa harus melihat ciri-ciri manusia pada negara-negara maju sebagai pembanding. Hal ini akan memaksakan diri seseorang untuk melakukan revolusi mental yang berorientasi pada pembangunan berkelanjutan yang dilandasi nilai-nilai liberal positif dalam Pancasila.

Nilai-nilai liberal menurut Puntsch (1996) ialah (1) kebebasan, (2) tang-gung jawab, (3) mewujudkan diri sendiri, (4) hak untuk menentukan sendiri, (5) turut menentukan, (6) toleransi, (7) menyeimbangkan kesempatan-kesempatan, (8) pertolongan agar dapat menolong diri sendiri, (9) pluralisme, (10) kemajuan, (11) demokrasi, (12) federalisme dan desentralisasi, (13) alam dan lingkungan hidup, dan (14) perdamaian. Nilai-nilai liberal tersebut bersifat positif sesuai dengan nilai dasar Pancasila.

Gaya liberal sebagai karakter manusia masa depan yang diharapkan dalam menyikapi masyarakat ekonomi ASEAN adalah (1) kritik pada diri sendiri, (2) diskusi, (3) keterbukaan, (4) rasionalisme, (5) keadilan, (6) kejujuran (Puntsch, 1996), (7) peduli lingkungan fisikal dan sosial (berwawasan kegeografian), (8) kolaborasi dalam membangun jejaring untuk kemajuan peradaban bangsa, dan (9) mentalitas pembangunan. Gaya liberal tersebut mencerminkan bahwa manusia seutuhnya bermental pembangunan semesta.

Caranya mengubah mentalitas lemah itu, dan membina suatu mentalitas yang berjiwa pembangunan. Koentjaraningrat (2015) mengajukan bahwa ada em-pat jalan yang harus dilakukan ialah (1) memberi contoh yang baik, (2) memberi perangsang yang cocok, (3) persuasi dan penerangan, dan (4) pembinaan dan pengasuhan suatu generasi baru untuk masa akan datang sejak kecil, dalam kalangan keluarga. Tujuan akhir pengubahan mentalitas tersebut adalah mewujud-kan manusia seutuhnya dengan indikasi cerdas dan waras sehingga mampu berkarya kreatif.

Memperhatikan tujuan pendidikan global di atas dikaitkan dengan pembinaan mentalitas manusia berjiwa pembangunan maka diharapkan moral manusia masa depan dapat terwujud melalui penerapan desain pembelajaran konstruktivistik, karena hakikat manusia sebagai pembangun ilmu. Manusia hidup di abad pengetahuan dituntut memiliki kemampuan, antara lain: (1) berpikir dan berbuat kritis, (2) kreativitas, (3) kolaborasi, (4) saling pengertian lintas budaya, (5) komunikasi, (6) menguasai komputer, dan (7) belajar sepanjang hayat.

Penguasaan pengetahuan secara core subjects tidaklah cukup. Pada abad pengetahuan atau abad ke-21, setiap orang dituntut memiliki kemampuan kreatif dan kritis, memiliki karakter yang kuat seperti bertanggung jawab, sosial, toleran, produktif, mandiri, adaptif, fleksibel, dan percaya diri yang didukung oleh kemampuan dalam memanfaatkan teknologi informasi dan berkomunikasi. Demikian, boleh dikatakan bahwa pendidikan abad pengetahuan didominasi oleh pendidikan berbasis ICT.

Diperlukan empat tujuan pendidikan dan penerapannya untuk dapat mencapai harapan di atas pada abad pengetahuan: (1) memberikan sumbangan kepada masyarakat (pekerjaan berbasis pengetahuan, partisipasi dalam ekonomi global), (2) mengembangkan bakat pribadi (mewujudkan potensi dengan dukungan piranti pengetahuan), (3) menunaikan tanggung jawab kemasyarakatan (terlibat aktif dan mengetahui proses pengambilan keputusan demokratis), dan (4) melanjutkan tradisi melalui membangun jati diri dan bersimpati secara mendalam terhadap multikultural (Ardhana, 2001).

Indonesia di tahun 2045, dari berbagai sumber dikatakan memiliki bonus demografi yang terus berlanjut dan akan berkontribusi atau sebaliknya berbencana pada berbagai sektor. Salah satu bonus tersebut adalah pada sektor pertumbuhan ekonomi yang akan mengalami masa kejayaan seperti ungkapan bahwa "In 2045 Indonesia better akan Brazil and China" (Prasetya, 2014; Sugiharto, 2012). Hal ini akan menjadi kenyataan kalau bangsa Indonesia memiliki kompetensi sebagai-mana digambarkan sebagai berikut. 


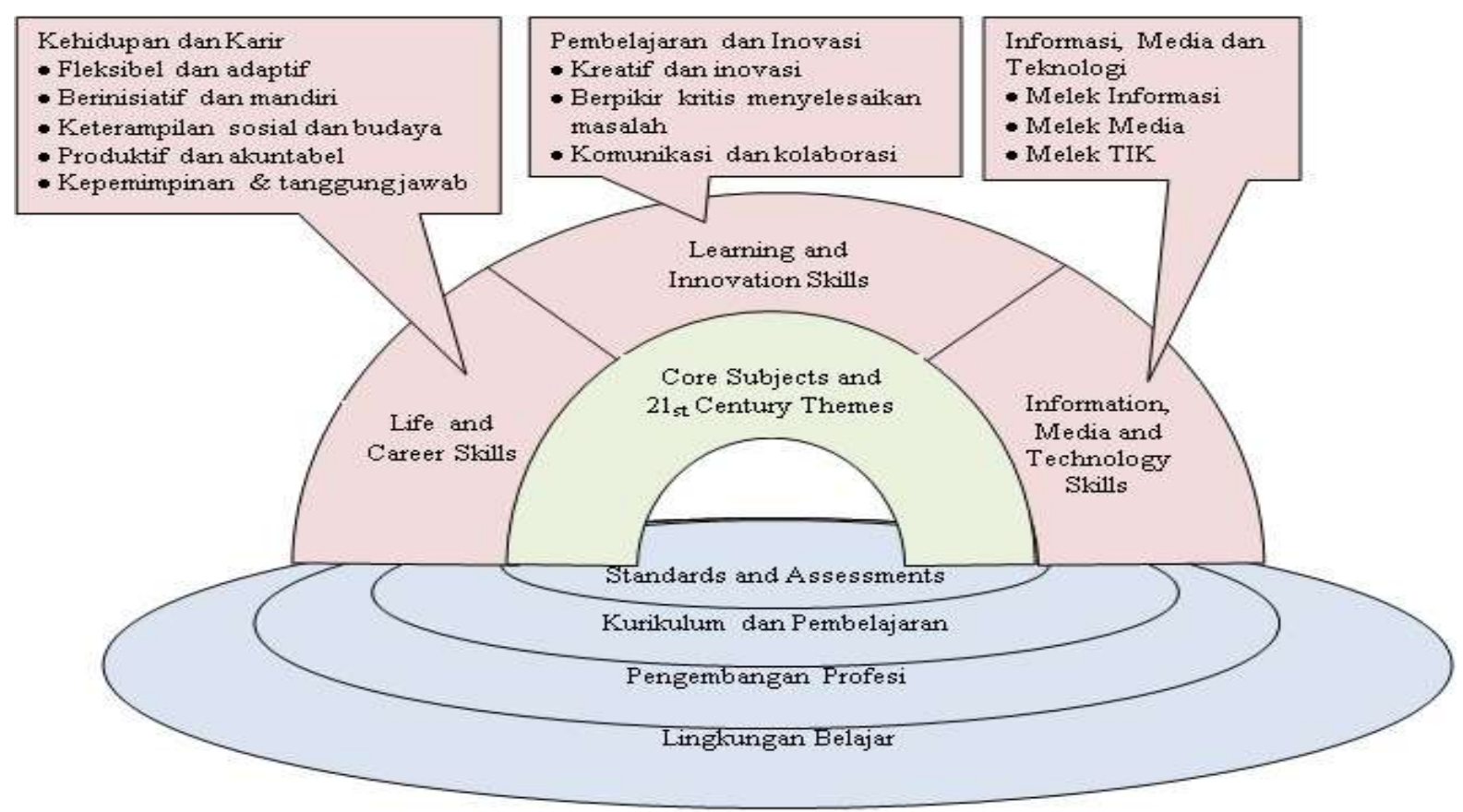

Gambar 2. Kerangka Kompetensi Manusia sebagai Tuntutan Abad Pengetahuan (Sumber: Permendikbud Nomor 59 Tahun 2014: 21; Hosnan, 2014)

\section{Keterampilan Dasar yang Dibutuhkan dalam MEA sebagai Tuntutan Abad Pengetahuan}

Ada tujuh jenis keterampilan dasar yang dibutuhkan kita untuk dapat hidup dalam masyarakat ekonomi ASEAN pada abad pengetahuan di samping keteram-pilan tradisional seperti membaca, menulis, dan menghitung. Jenis keterampilan tersebut sebagai berikut.

1) Berpikir dan Berbuat secara Kritis

Setiap manusia sebagai sumber daya pembangunan yang berkualitas harus mampu mendefinisikan masalah dalam domain yang kompleks, tumpang tindih dan tidak terdefinisikan dengan baik, menggunakan peralatan dan keahlian yang ada untuk keperluan analisis dan riset, merancang peme-cahan masalah yang menjanjikan harapan, mengelola implementasinya, menilai hasilnya dan secara terus menerus memperbaikinya sesuai dengan perubahan kondisi. Keterampilan berpikir dan berbuat secara kritis, misalnya memecahkan masalah secara holistik dan komprehensif, melakukan penyeli-dikan, melakukan analisis secara cermat dan benar, mengelola proyek secara profesional.

2) Kreativitas

Setiap manusia sebagai sumber daya pembangunan yang berkualitas diharapkan berhasil memecahkan masalah lama dengan cara pemecahan baru, menemukan prinsip-prinsip baru, menciptakan produk-produk baru, menciptakan cara baru dalam mengomunikasikan ide-ide baru, menemukan cara-cara kreatif untuk mengelola proses yang kompleks dan memperlihatkan kemampuan dalam bekerja dengan anggota-anggota tim yang beraneka ragam. Keterampilan kreativitas menuntut kita menciptakan pengetahuan baru, merancang solusi permasalahan, membuat karya kreatif inovatif keindonesiaan, menceritakan atau menjelaskan dengan benar, jelas, dan menarik.

3) Kolaborasi

Kerja tim merpakan pilihan utama sebagai upaya memecahkan masalah yang kompleks atau menciptakan piranti, jasa dan produk kompleks, karena dalam kerja tim berbagai bakat dan kemampuan diperlukan. Keterampilan yang diperlukan pada abad pengetahuan bervariasi mulai dari kemapuan koordinasi dan kolaborasi sampai pada kemampuan membuat kompromi dan mencapai konsensus. Keterampilan kolaborasi meliputi bekerja 
sama yang solid, melakukan kompromi atau negosiasi untuk kebaikan bersama, membuat konsesus, dan membangun lingkungan masya-rakat. Kolaborasi untuk mencapai kesejahteraan bersama dengan menekan-kan sama-sama untung (win win solution).

4) Saling Pengertian Lintas Budaya

Setiap manusia sebagai sumber daya pembangunan, perlu melakukan upaya-upaya untuk menjembatani perbedaan-perbedaan etnik, sosial, organisasi politik, dan isi pengetahuan yang bersifat budaya. Sekarang ini masyarakat Indonesia dan dunia berkembang menjadi multikultural dan berkembangnya ekonomi global, keterampilan lintas budaya akan memain-kan peran yang makin penting dan mendesak, terutama dalam penyeleng-garaan MEA. Keterampilan saling pengertian lintas budaya, misalnya lintas etnik, lintas pengetahuan, lintas budaya organisasi, dan lintas negara. Kete-rampilan ini sangat penting untuk mendukung perdagangan bebas di kawasan Asia Tenggara bahkan dunia.

5) Komunikasi

Setiap manusia sebagai sumber daya pembangunan yang berkualitas perlu memiliki kemampuan melakukan komunikasi secara efektif dalam berbagai me-dia, untuk kepeluan berbagai audien, dan kemampuan memilih media yang sesuai dengan jenis dan sifat pesan. Keterampilan komunikasi sebagai salah satu tuntutan dalam menjalani hidup bersama masyarakat ekonomi Asean pada abad pengetahuan, misalnya mampu membangun komunikasi efektuf atau membangun jejaring, menyampaikan pesan dengan jelas dan menarik, dan menggunakan media secara efektif untuk mempre-sentasian karya kreatif keindonesiaan dalam kancah perdagangan bebas MEA.

6) Menggunakan Komputer dan Internet

Setiap orang di abad pengetahuan dituntut dengan mudah dapat menggunakan komputer dan internet secara lebih baik. Begitu juga, setiap orang diharapkan sanggup memanfaatkan peranti-piranti berbasis komputer dalam melakukan pekerjaannya sehari-hari. Mereka yang mampu menggu-nakan piranti pengetahuan akan lebih berhasil di sekolah atau dalam melak-sanakan pekerjaannya. Keterampilan penggunaan komputer dan internet sangat dibutuhkan sebagai tuntutan abad pengetahuan, misalnya mengguna-kan informasi elektronik secara efektif dan pemanfaatan peralatan pengeta-huan. Bisnis dan belajar melalui online sangat perlu dalam mendukung efektivitas perdagangan bebas MEA.

7) Mengembangkan Karier dan Belajar Mempercayai Diri Sendiri

Pekerja pengetahuan harus mampu mengelola sendiri jalur kariernya dan mempunyai kemampuan untuk mempelajari keterampilan baru secara berkelanjutan. Hal ini disebabkan sebagian besar pekerjaan berbasis proyek yang memerlukan keterampilan tingkat tinggi, maka kemapuan dalam mengola peralihan dari satu proyek ke proyek lainnya serta cepat mempel-ajari hal-hal baru yang dibutuhkan sangat penting artinya bagi daya survival karier seseorang. Pengembangan karier dan belajar meyakini kemampuan sendiri sebagai tuntan abad pengetahuan. Kita perlu mengelola perubahan, belajar sepanjang hayat, dan mendefinisikan kembali karier yang ditekuni. Kita dituntut mengembangkan karya asli keindonesian yang menjadi andalan dan menghargai karya bangsanya.

\section{Usaha Meningkatkan Kualitas SDM Indonesia dalam Menyikapi MEA melalui Geografi sebagai Pendidikan Global}

Geografi ialah bidang ilmu integratif yang mempelajari fenomena fisikal dan sosial di permukaan bumi dengan perspektif keruangan untuk pengelolaan atau pembangunan wilayah supaya manusia hidup sejahtera (Khafid, 2013). Geografi mempelajari bumi dan manusia dengan sudut pandang sistem keruangan. Dalam konteks pendidikan global, Bonnett (2008) mendefinisikan geografi ialah disiplin dunia (geography is the world discipline).

Pendidikan global ialah sebuah pendekatan baru di bidang pendidikan yang menumbuhkan kesadaran lintas budaya, kerja sama, dan pemahaman fenomana mondial dengan tujuan mempersiapkan siswa untuk memahami dan mengatasi adanya saling ketergantungan global dan keragaman budaya, yang mencakup hubungan, kejadian, dan 
kekuatan yang tidak dapat diisikan ke dalam batas-batas negara dan budaya. Pendidikan global mengharuskan manusia hidup bersama dan memberi manfaat satu dengan yang lain.

Sumaatmadja \& Wihardit (2009) menjelaskan pendidikan global ialah "upaya sistematis untuk membentuk wawasan dan perspektif peserta didik, karena pendidikan global mereka dibekali materi yang bersifat utuh dan menyeluruh yang berkaitan dengan masalah global". Pendidikan global menawarkan suatu makna bahwa kita hidup di dalam masyarakat manusia, suatu perkampungan global di dalam mana manusia dihubungkan, baik suku maupun bangsa dan batas negara tidak menjadi penghalang serta sebagai komunitas dari perbedaan di antara orang-orang yang berbeda bangsa. Kalau begitu, yang paling relevan sebagai pendidikan global adalah geografi dunia ialah yang menumbuhkan kesadaran lintas budaya, kerja sama, dan pemahaman fenomana fisikal dan sosial di dunia.

Geografi sebagai pendidikan global ialah pembelajaran dengan perspektif spasial global, yakni: (1) mengenali saling ketergantungan dan keterkaitan antara isu-isu, daerah, masyarakat, tempat, sistem, dan waktu; (2) meningkatkan pema-haman isu-isu global seperti pembangunan berkelanjutan, pengelolaan lingkung-an, perdamaian, dan hak asasi manusia ke dalam bidang subjek tradisional, dan (3) bekerja sebagian kewarganegaraan global yang aktif, bertanggung jawab dan membangun sebuah dunia yang lebih damai, adil, dan berkelanjutan.

Geografi sebagai pendidikan global bertujuan mempersiapkan peserta didik untuk memahami dan mengatasi adanya saling ketergantungan global dan keragaman budaya, yang mencakup hubungan, kejadian, dan kekuatan yang tidak dapat diisikan ke dalam batas-batas negara dan budaya. Hoopes (Sumaatmadja dan Wihardit, 2009) menjelaskan bahwa pendidikan global memiliki tiga tujuan yakni memberikan pengalaman (1) mengurangi rasa kedaerahan dan kesukuan. Tujuan ini dapat dicapai melalui mengajarkan bahan dan menggunakan metode yang memberikan relativisme budaya, (2) mempersiapkan siswa untuk mendekatkan diri dengan keragaman global. Kegunaan tujuan ini adalah untuk mendiskusikan relativisme budaya dan keutamaan etika, dan (3) membelajarkan siswa untuk berpikir tentang mereka sendiri sebagai individu, sebagai warga suatu negara, dan bahkan sebagai anggota masyarakat global (global citizen).

Pertumbuhan umat manusia dengan segala kebutuhannya yang multiaspek, tidak lagi dapat terpenuhi oleh sumber daya yang hanya tersedia secara lokal di tempat masing-masing. Sumaatmadja (2000) berpendapat bahwa kelangkaan dan keterbatasan sumber daya tadi secara lokal, harus diantisipasi oleh manusia sendiri dengan melakukan "penjelajahan spasial". Gerak dan tindakan spasial tersebut mendorong usaha manusia mengembangkan teknologi komunikasi, transportasi, dan informasi. Melalui media tersebut yang makin meluas, penjelajahan manusia di permukaan bumi termasuk cakrawala pandangannya juga makin meluas.

Sudut pandang (viewpoint) atau dalam bahasa Indonesia biasa diungkap-kan juga sebagai wawasan, merupakan suatu kemampuan bagaimana kita meman-dang sesuatu secara luwes, mendalam, dan bermakna dalam cakrawala yang luas. Pada konotasi perspektif global, sudut pandang itu, secara holistik melingkupi fenomena-fenomena yang mendunia melintas batas-batas bangsa dan negara. Cara pandang atau wawasan yang demikian itu, menjadi tuntutan ke kemampuan bagi setiap orang sebagai anggota warga dunia (global citizen), terutama bagi mereka yang memegang kebijakan dan keputusan yang berskala internasional atau dunia. Sudut pandang yang luas dan luwes ini, bagi setiap orang sebagai warga dunia itu, sangat bermakna dan strategis dalam menempatkan diri sesuai dengan kemajuan peradaban dalam arti seluas-luasnya.

Ada lima dimensi dasar perspektif global yang memfokuskan kembali siswa dari kesadaran nilai-nilai kepercayaan mereka sendiri secara eksklusif supaya menjadi sadar bahwa dunia terdiri atas orang-orang dengan sudut pandang yang berbeda, tetapi tidak selalu mengancam diri mereka. Siswa kemudian menyadari bahwa perspektif-perspektif tersebut ternyata tidak hanya nyata tetapi perlu dihormati, yakni (1) kesadaran perspektif, (2) 
pengetahuan tentang kondisi dunia, (3) kesadaran lintas budaya, (4) pengetahuan tentang dinamika global, dan (5) pengetahuan tentang alternatif (kesadaran pilihan manusia).

Perspektif kurikuler pendidikan global berarti menyajikan kurikulum yang bersifat interdisipliner, multidisipliner, dan transdisipliner. Berdasarkan perspektif reformasi, pendidikan global menuntut kebijakan bukan hanya sebagai kebijakan sosial, melainkan juga kebijakan yang mendasarkan mekanisme pasar. Karena itu, pendidikan harus berkebebasan dan bersifat demokratis, fleksibel, dan adaptif. Peran pendidikan global untuk menyiapkan manusia menjadi citizen of the world yang memahami masyarakat dari berbagai perspektif dan tempat tentang segala hal (Khafid, 2009). Geografi sebagai pendidikan global mengharuskan orang untuk (1) menjalani kehidupan bukan hanya sebagai orang Indonesia, melainkan sebagai masyarakat global, (2) dinamis dan fleksibel, serta mendorong manusia untuk belajar terus menerus, dan (3) membantu peserta didik untuk memahami keragaman perspektif dari berbagai belahan dunia. Dengan pendidikan global tersebut, diharapkan peserta didik memiliki kemampuan belajar sepanjang hayat dalam memahami isu-isu global. Pendidikan global dapat meningkatkan kualitas sumber daya manusia Indonesia yang siap menjalani hidup dan kehidupan dalam masyarakat ekonomi ASEAN dengan percaya diri karena memiliki kompetensi dan harga diri.

Melalui geografi sebagai pendidikan global, dipercaya bahwa sebuah pemahaman lebih mendalam tentang dunia dan penduduknya adalah sebuah upaya penting, sebagaimana Johnston menyatakan sebagai berikut. World understanding is fundamental to world peace and ultimately to world survival. Ignorance leads to the development of stereotypes, negative reactions to other peoples and cultures which breed hostility. Geography must be use to break down those barriers of ignorance (Johnston, 1984). Peran geografi sebagai pendidikan global diharapkan dapat membantu mengurangi pemikiran dan tindakan stereotipikal, negatif, dan pejoratif terhadap orang-orang, budaya, bangsa, dan negara. Pendidikan global termasuk pendidikan geografi dapat peran penting untuk meningkatkan kualitas sumber daya manusia yang berwawasan global bahkan mondial yang siap menjalani hidup pada abad pengetahuan yang penuh gejolak dan tantangan.

\section{Simpulan dan Saran}

Indonesia masih berparadoksial ialah suatu kondisi nyata dengan pernya-taan yang seolah-olah bertentangan (perlawanan) dengan pendapat umum/publik atau kebenaran, tetapi kenyataannya mengandung kebenaran). Penyebab utama ialah penyakit atau virus orientasi. Orientasi merupakan penyakit mental sebagai penghambat pembangunan. Oleh karena itu, manusia Indonesia perlu berkarakter.

Karakter manusia Indonesia yang dituntut abad pengetahuan dan MEA yakni: cerdas dan waras yang menerapkan nilai-nilai dasar Pancasila dalam kehidupan berbangsa sekaligus sebagai anggota masyarakat global. Gaya liberal sebagai karakter manusia masa depan: (1) kritik pada diri sendiri, (2) diskusi, (3) keterbukaan, (4) rasionalisme, (5) keadilan, (6) kejujuran, (7) peduli lingkungan fisikal dan sosial, (8) kolaborasi membangun jejaring, dan (9) mentalitas pemba-ngunan.

Jenis keterampilan dasar yang dibutuhkan manusia Indonesia untuk dapat hidup dalam MEA pada abad pengetahuan di samping keterampilan tradisional seperti membaca, menulis, menghitung, yaitu (1) berpikir dan berbuat secara kritis, (2) kreativitas, (3) kolaborasi, (4) saling pengertian lintas budaya, (5) komunikasi, (6) menggunakan komputer dan internet, dan (7) karier dan belajar mempercayai diri sendiri. Keterampilan dasar manusia seutuhnya adalah budaya membaca tinggi dan produktif berupa karya tulis ilmiah dan karya seni bercorak keindonesiaan tetapi berwawasan mondial.

Geografi sebagai pendidikan global dapat membantu manusia memahami dan merefleksikan keadaan masyarakat global. Artinya, bangsa Indonesia sebaik-nya menjalani kehidupan bukan hanya sebagai orang Indonesia, melainkan seba-gai masyarakat global. Geografi mengajarkan orang-orang untuk dinamis dan fleksibel, serta mendorong masyarakat 
untuk belajar sepanjang hayat. Ketika berbicara tentang spasial global maka terjadi hubungan timbal balik dipengaruhi oleh orang lain.

\section{Daftar Pustaka}

Ardhana, W. (2001). Reformasi Pembelajaran Menghadapi Abad Pengetahuan. In Kuliah Perdana. Surabaya: Program Pascasarnana Teknologi Pembelajaran Universitas PGRI Adi Buana.

Bagir, H. (2019). Memulihkan Sekolah Memulihkan Manusia: Meluruskan Kembali Falsafah Pendidikan Kita (Cetakan Ke). Bandung: Mizan.

Bonnett, A. (2008). What is Geography? (First Publ). London: SAGE Publications.

Dahliyana, A. (2017). Penguatan Pendidikan Karakter Melalui Kegiatan Ekstrakurikuler Di Sekolah. Sosio Religi Jurnal Pendidikan Umum/Nilai, 15(1), 1-10.

Hamzah, A. (2019). Metode Penelitian Kepustakaan: Kajian Filosofis, Teoretis, dan Aplikatif. Malang: Literasi Nusantara.

Hosnan, M. (2014). Pendekatan Saintifik dan Kontekstual dalam Pembelajaran Abad 21. Jakarta: Ghalia Indonesia.

Ismuha, \& Dkk. (2016). Kompetensi Manajerial Kepala Sekolah Dalam Meningkatkan Kinerja Guru Pada SD Negeri Lamklat Kecamatan Darussalam Kabupaten Aceh Besar. Jurnal Administrasi Pendidkan, 4(1), 46-55.

Johnston, R. (1984). The World Is Our Oyster. Transactions of the Institute of British Geographers, 9(4), 43-59.

Khafid, S. (2009). Pendidikan Global. Fokus, 27(2).

Khafid, S. (2013). Pengantar Geografi Pemahaman Paradigma Geografi Sejati (Cetakan Ke). Surakarta: UNS Press.

Koentjaraningrat. (2015). Kebudayaan, Mentalitas dan Pembangunan (Cetakan Ke). Jakarta: Gramedia.

Muzakki, H. (2015). Managing Learning for Quality Improvement (Mengelola Pembelajaran untuk Peningkatan Mutu). An-Nuha, 2(2).

Prasetya, S. M. (2014). Media Pembelajaran Geografi. Yogyakarta: Penerbit Ombak.

Puntsch, E. (1996). Politik dan Martabat Manusia: Tingkah Laku yang Liberal. Jakarta: Pustaka Sinar Harapan.

Shihab, N., \& Komunitas Guru Belajar. (2017). Merdeka Belajar di Ruang Kelas. Tanggerang Selatan: Literasi.

Sugiharto. (2012). Menyongsong Indonesia Emas 2045. In Kuliah Perdana. Yogyakarta: UST.

Sumaatmadja, N. (2000). Manusia dalam Konteks Sosial, Budaya, dan Lingkungan Hidup. Bandung: Alfabeta.

Sumaatmadja, N., \& Wihardit, K. (2009). Perspektif Global. Jakarta: UT.

Sumaryono, E. (1999). Hermeneutik Sebuh Metode Filsafat (Cetakan Ke). Yogyakarta: Kanisius.

Thobroni, M., \& Mustofa, A. (2011). Belajar \& Pembelajaran Pengembangan Wacana dan Praktik Pembelajaran dalam Pembangunan Nasional. Yogyakarta: AR-RUZZ Media.

Triyonggo. (2015). Analisis Situasional Kompetensi Praktisi Sumber Daya Manusia Indonesia Menghadapi MEA 2015. Jurnal Manajemen Teknologi, 14(1), 100-111.

Utami, S., Sakitri, W., \& Sebayang, L. K. B. (2016). Peningkatan Kualitas Sumber Daya Guru Dan Siswa Sekolah Menengah Kejuruan (SMK) Melalui Pengembangan Inovasi Bahan Ajar Berbasis English For Specific Purposes (ESP). Abdimas, 20(2), 125-132. 